\title{
Determination of Natural Radionuclides Concentrations in Surface Soil in Tafila/Jordan
}

\author{
O. Abu-Haija \\ Applied Physics Department, Tafila Technical University \\ PO box 179, Tafila 66110, Jordan \\ E-mail: oabuhaija@ttu.edu.jo
}

Received: January 4, 2012

Accepted: February 29, 2012 Published: March 1, 2012

doi:10.5539/mas.v6n3p87

URL: http://dx.doi.org/10.5539/mas.v6n3p87

\begin{abstract}
A first comprehensive study is presented on natural radionuclide activity concentrations in surface soils in different divisions of Tafila city. The natural radioactivity of ${ }^{238} \mathrm{U},{ }^{232} \mathrm{Th}$ and ${ }^{40} \mathrm{~K}$ is determined using gamma spectroscopy. The soil activity concentrations ranged from 1.8 to $76.4 \mathrm{~Bq} \mathrm{~kg}^{-1}$ for ${ }^{238} \mathrm{U}, 6.3$ to $85.5 \mathrm{~Bq} \mathrm{~kg}^{-1}$ for ${ }^{232} \mathrm{Th}$, and 84 to $516.7 \mathrm{~Bq} \mathrm{~kg}^{-1}$ for ${ }^{40} \mathrm{~K}$. The activity concentrations of the radionuclide in soils are directly relevant to outdoor exposure. Absorbed dose rates in air outdoors were calculated to be in the range of $22.28-$ $62.71 \mathrm{nGy} \mathrm{h}^{-1}$ with an overall average value of $40.12 \mathrm{nGy} \mathrm{h}^{-1}$. The study showed an annual effective dose equivalent in the range of $27.34-76.96 \mu \mathrm{Sv} \mathrm{y}^{-1}$. A comparison of the measured values with the corresponding worldwide average values shows that the activities of natural radionuclides in the studied samples are below the world average activity values.
\end{abstract}

Keywords: Radioactivity concentrations, HPGe gamma spectrometry, ${ }^{40} \mathrm{~K},{ }^{232} \mathrm{Th},{ }^{238} \mathrm{U}$

\section{Introduction}

Radionuclides have been present always in every environment of the earth's surface. Only nuclides with half-lives comparable to the age of the earth or their corresponding decay products, existing in terrestrial materials, can still be found today on earth, e.g. ${ }^{40} \mathrm{~K}$, and the radionuclides from the ${ }^{238} \mathrm{U}$ and ${ }^{232} \mathrm{Th}$ series (UNSCEAR, 2000). Gamma radiation, emitted from these naturally occurring radionuclides and from radionuclides deposited on the ground, represents the main external source of irradiation of the human body. It is generally realized that natural environmental radioactivity and the associated external exposure due to gamma-radiation depend primarily on the geological and geographical conditions, and appear at different levels of radionuclides in the soils of each region in the world (Shenber, 1997; Karahan, et al., 2000; Chikasawa, et al., 2001; AL-Masri, et al., 2006). Therefore, to evaluate the dose rate caused by these radionuclides, their concentrations in soil have to be determined. It turned out that understanding the behavior of natural radionuclides in environment is so important, because such information can be used as the associated parameter values for radiological estimations (Vera Tome, et al., 2003). It is interesting to mention that only few previous studies were conducted to determine the radioactivity levels and associated dose rates from surface soils in Jordan. Among them, Ahmad et al. (1997) have been measured the indoor radon concentration levels and natural radioactivity in soil in different areas of Jordan. Al-Hamarneh et al. (2003) have made a study on surface and core soil samples collected from different regions of Jordan. In their work, they focused on measuring the concentrations of artificial radionuclides. The estimations of the annual effective dose equivalent due to ${ }^{137} \mathrm{Cs}$ were found to have values more than $200 \mu \mathrm{Sv}$. AL-Jundi (2002) has found that the values of the concentrations of ${ }^{40} \mathrm{~K}$ and ${ }^{232} \mathrm{Th}$ are normal in comparison to other worldwide standards in other countries, while the concentrations of ${ }^{238} \mathrm{U}$, in samples obtained from old phosphate mine, are much more higher than the worldwide range. Similar study has been made by AL-Jundi et al. (2003) on a measurement of the specific activity and the gamma-ray absorbed doses of the naturally occurring radionuclides in soil cores obtained from eight sites along Amman Aqaba National Highway. Recently, Kharisat (2010) has used alpha spectrometry technique to measure the specific activity of ${ }^{238} \mathrm{U}$ in soil and vegetables of Tafila city. In this paper, an attempt has been made to determine the concentration of ${ }^{40} \mathrm{~K},{ }^{232} \mathrm{Th}$ and ${ }^{238} \mathrm{U}$ in soil samples collected from ten different divisions of Tafila city using HPGe gamma ray spectrometer and to compute the total absorbed gamma dose rate in air due to the presence of ${ }^{40} \mathrm{~K},{ }^{232} \mathrm{Th}$ and ${ }^{238} \mathrm{U}$ in the samples. 


\section{Experimental}

A total of fifty samples were collected from ten divisions (samples from five selected sites of each division) at 0 - $10 \mathrm{~cm}$ depth level all over Tafila city. These samples were collected from uncultivated fields using a stainless steel template. The samples were first crushed and milled to a fine powder. Then, they oven dried at temperature of $70{ }^{\circ} \mathrm{C}$ for 24 hours to ensure that moisture was completely removed and sieved through a $1 \mathrm{~mm}$ mesh to remove stone, pebbles and other macro-impurities. Last, each sample was weighed, carefully sealed in standard plastic Marinelli beakers prior being taken for gamma spectrometric analysis.

The spectral analysis of the radionuclides of these samples was carried out using a $\gamma$-ray spectrometer equipped with high purity germanium (HPGe) detector of $20 \%$ relative efficiency and an energy resolution (FWHM) of $1.8 \mathrm{keV}$ for the $1.33 \mathrm{MeV}$ reference transition of ${ }^{60} \mathrm{Co}$. The detector was placed inside a thick lead shield to reduce the background radiation. The detector output signal was taken to the PC equipped with a MCA (Multi Channel Analyzer, model DSA-1000). The software utilized for data acquisition is Canberra software package Genie-2000, including peak search and nuclide identification modules. The system was calibrated for energy and efficiency on a regular basis. The energy calibration was carried out by acquiring a spectrum from certified calibration sources of known energies such as ${ }^{60} \mathrm{CO}$, for $\mathrm{E}_{\gamma}=1332.5$ and $1173.2 \mathrm{keV}$, and ${ }^{137} \mathrm{Cs}$, for $\mathrm{E}_{\gamma}=661.6$ $\mathrm{keV}$. The detector energy-dependent efficiency was determined using reference samples (RGU, RGTH and RGK) provided by the International Atomic Energy Agency, IAEA in the same geometry as the measured samples. The gamma-rays of interest ranged from $50-3000 \mathrm{keV}$. The prepared Marinelli beakers (samples) were placed on the detector end cap a distance $10 \mathrm{~mm}$ approximately. Each sample was counted for a period of 10 hours to obtain good statistics and the dead time was smaller than $10 \%$. Measurements with an empty Marinelli beaker, under identical conditions, were also carried out to determine the background counts. The latter was subtracted from the measured spectra of each sample to obtain the net radionuclide activities.

\section{Results and Discussion}

The measured activity concentrations of the natural radionuclides ${ }^{238} \mathrm{U},{ }^{232} \mathrm{Th}$ and ${ }^{40} \mathrm{~K}$ for the collected samples from Tafila city are shown in Table 1 . The activity concentration of each radionuclide was measured for five different samples coming from the same site and then averaged. The concentrations of ${ }^{238} \mathrm{U}$ were in the range of 1.8 to $76.4 \mathrm{~Bq} \mathrm{~kg}{ }^{-1}$ with a mean value of $22.03 \mathrm{~Bq} \mathrm{~kg}^{-1}$. It can be seen in this table that the mean activity concentrations of ${ }^{232} \mathrm{Th}$ and ${ }^{40} \mathrm{~K}$ were $27.91 \mathrm{~Bq} \mathrm{~kg}^{-1}$ and $285.02 \mathrm{~Bq} \mathrm{~kg}^{-1}$, respectively. A mean value of $17.9 \mathrm{~Bq}$ $\mathrm{kg}^{-1}$ for ${ }^{232} \mathrm{Th}$ and $558.4 \mathrm{~Bq} \mathrm{~kg}{ }^{-1}$ for ${ }^{40} \mathrm{~K}$ were measured in soils collected in 1997 from Tafila city (Ahmed, et al., 1997). Our result for ${ }^{232} \mathrm{Th}$ is seen to fall above the previous measured value of Ahmad et al. (1997). However, our result for ${ }^{40} \mathrm{~K}$ is less than their result by a factor of two. The variation in the results can be attributed to many factors like number of soil samples, soil characteristics and location of the sites. Another comparison can be made between our results and that of UNSCEAR (2000) report. According to this report, the worldwide average concentration values of the natural radionuclides ${ }^{238} \mathrm{U},{ }^{232} \mathrm{Th}_{\text {and }}{ }^{40} \mathrm{~K}$ are $40 \mathrm{~Bq} \mathrm{~kg}^{-1}, 40 \mathrm{~Bq} \mathrm{~kg}^{-1}$ and $370 \mathrm{~Bq} \mathrm{~kg}^{-1}$, respectively. It is obvious that our findings are in general agreement with the worldwide measured values. Table 2 presents the activity concentrations of natural radionuclides in soil samples of different regions in the world. The comparison of our findings of the activity concentration with those obtained by other workers worldwide, reveals that we have reasonable values.

In this work, the estimate of the absorbed gamma dose rate in outdoor air was calculated using the following formula (Chikasawa, et al., 2001):

$$
\text { Dose rate }\left(\mathrm{nGy} \mathrm{h}^{-1}\right)=\text { Concentration of nuclide } \times \text { Conversion factor }
$$

Here the conversion factor is $0.427 \mathrm{nGy} \mathrm{h}^{-1} / \mathrm{Bq} \mathrm{kg}^{-1}$ for ${ }^{238} \mathrm{U}, 0.662 \mathrm{nGy} \mathrm{h}^{-1} / \mathrm{Bq} \mathrm{kg}^{-1}$ for ${ }^{232} \mathrm{Th}^{-1}$ and $0.043 \mathrm{nGy}$ $\mathrm{h}^{-1} / \mathrm{Bq} \mathrm{kg}^{-1}$ for ${ }^{40} \mathrm{~K}$. The calculations for the absorbed dose rates were made for a height of one meter above the ground surface from different locations, assuming that naturally occurring radionuclides are uniformly distributed in the ground. In addition, the absorbed doses were calculated only from outdoor terrestrial gamma radiation.

Furthermore, the effective dose outdoors over one year was calculated based on UNSCEAR reports $(1993,2000)$ using the following relation:

$$
\text { Effective dose rate }\left(\mathrm{Sv} \mathrm{y}^{-1}\right)=\text { Dose rate }\left(\mathrm{nGy} \mathrm{h}^{-1}\right) \times 8766 \mathrm{~h} \times 0.2 \times 0.7 \mathrm{mSv} \mathrm{Gy}^{-1}
$$

where 0.2 is the occupancy factor and 0.7 is the conversion coefficient.

The total absorbed gamma dose rate in air outdoors, $D\left(\mathrm{nGy} \mathrm{h}^{-1}\right)$, along with the annual committed effective dose equivalent, $E\left(\mu \mathrm{Sv} \mathrm{y}^{-1}\right)$, due to external exposure of ${ }^{238} \mathrm{U},{ }^{232} \mathrm{Th}$ and ${ }^{40} \mathrm{~K}$ in soil of Tafila city are summarized in Table 3. The $D$-values were in the range 22.28 to $62.71 \mathrm{nGy} \mathrm{h}^{-1}$ with an overall average value of $40.12 \mathrm{nGy} \mathrm{h}^{-1}$. 
The results are in agreement with the average world figures. The dose rate in air outdoors from terrestrial gamma rays in normal circumstances is around $57 \mathrm{nGy} \mathrm{h}^{-1}$, while the national averages ranges between 24 to $160 \mathrm{nGy}$ $\mathrm{h}^{-1}$ according to the report of UNSCEAR (2000). The $E$-values, on the other hand, were in the range of 27.34-76.96 $\mu \mathrm{Sv} \mathrm{y}^{-1}$ with an overall average value of $49.26 \mu \mathrm{Sv} \mathrm{y}^{-1}$. It is clear that the average value of the annual effective dose $\left(0.049 \mathrm{mSv} \mathrm{y}^{-1}\right)$ obtained from Tafila city is lower than the worldwide average value for outdoor effective dose of $0.07 \mathrm{mSv} \mathrm{y}^{-1}$, reported by UNSCEAR (2000).

\section{Conclusions}

To conclude, a study on natural radionuclide activity concentrations in surface soils of randomly selected divisions in Tafila city has been reported. The mean activity of ${ }^{238} \mathrm{U},{ }^{232} \mathrm{Th}$ and ${ }^{40} \mathrm{~K}$ were found to be $22.03,27.91$ and $285.02 \mathrm{~Bq} \mathrm{~kg}^{-1}$, respectively. Despite the fluctuation in the measurements of the activity concentrations of each natural radionuclide ${ }^{238} \mathrm{U},{ }^{232} \mathrm{Th}$ and ${ }^{40} \mathrm{~K}$ in the studied soil samples, the data are found to be normal in comparison to the worldwide standards in other countries. The results for dose rate in air outdoors from terrestrial gamma rays are in agreement with the average world values. The annual effective dose was found to be $0.049 \mathrm{mSv} \mathrm{y}^{-1}$, which is well below the permissible dose equivalent. This study is a complementary work added to other works on Jordan environment in order to establish a baseline data for radioactivity levels in the Jordan environment.

\section{References}

Ahmad, N., Matiullah, \& Khatibeh, A. J. A. H. (1997). Indoor Radon Levels and Natural Radioactivity in Jordanian Soil. Radiat. Prot. Dosim., 71(3), 231 - 233. http://rpd.oxfordjournals.org/content/71/3/231

Al-Hamarneh, I., Wreikat, A., \&Toukan, K. (2003). Radioactivity Concentrations of ${ }^{40} \mathrm{~K},{ }^{134} \mathrm{Cs},{ }^{137} \mathrm{Cs},{ }^{90} \mathrm{Sr}$, ${ }^{241} \mathrm{Am},{ }^{238} \mathrm{Pu}$ and ${ }^{239+240} \mathrm{Pu}$ Radionuclides in Jordanian Soil Samples. J. Environ. Radioact., 67, 53-67. http://dx.doi.org/10.1016/S0265-931X(02)00160-1

Al-Jundi, J. (2002). Population Doses from Terrestrial Gamma Exposure in Areas Near to Old Phosphate Mine, Russaifa, Jordan. Radiat. Meas., 35, 23 - 28. http://dx.doi.org/10.1016/S1350-4487(01)00261-X

Al-Jundi, J., Al-Bataina, B. A., Abu-Rukah, Y., \& Shehadeh, H. M. (2003). Natural Radioactivity Concentrations in Soil Samples Along the Amman Aqaba Highway, Jordan. Radiat. Meas., 36, 555-560. http://dx.doi.org/10.1016/S1350-4487(03)00202-6

Al-Masri, M. S., Amin, Y., Hassan, M., Ibrahim, S., \& Khalili, H. S. (2006). External Gamma-Radiation Dose to Syrian Population Based on the Measurement of Gamma-Emitters in Soils. J. Radioanalytical and Nucl. Chem., 267(2), 337 - 343. http://dx.doi.org/10.1007/s10967-006-0052-6

Chikasawa, K., Ishii, T., \& Sugiyama, H. (2001). Terrestrial Gamma Radiation in Kochi Prefecture, Japan. J. Health Sci., 47(4), 362 - 372. http://jhs.pharm.or.jp/data/47(4)/47(4)p362.pdf

Kannan, V., Rajan, M. P., Iyengar, M. A. R., \& Ramesh, R. (2002). Distribution of Natural and Anthropogenic Radionuclides in Soil and Beach Sand Samples of Kalpakkam (India) Using Hyper Pure Germanium (HPGe) Gamma Ray Spectrometry. Appl. Radiat. Isot., 57, 109-119. http://dx.doi.org/10.1016/S0969-8043(01)00262-7

Karahan, G., \& Bayulken, A. (2000). Assessment of Gamma dose Rates around Istanbul (Turkey). J. Environ. Radioact., 47, 213 - 221. http://dx.doi.org/10.1016/S0265-931X(99)00034-X

Kharisat, K. (2010). Measurement of Some Alpha-Emitters Concentrations in Soil and Vegetable Samples in Tafila District. Ms. Sc., Thesis, Physics Department, Yarmouk University, Irbid-Jordan.

Shenber, M. A. (1997). Measurement of Natural Radioactivity Levels in Soil in Tripoli. Appl. Radiat. Isot., 48(1), 147 - 148. http://dx.doi.org/10.1016/S0969-8043(96)00065-6

UNSCEAR. (1993). United Nation Scientific Committee on the Effect of Atomic Radiation. Report to General Assembly with Scientific Annexes, United Nations, New York.

UNSCEAR. (2000). Sources and Effects of Ionizing Radiations. Report to General Assembly with Scientific Annexes, United Nations, New York.

Vera Tome, F., Blanco Rodri'guez, M. P., \& Lozano, J. C. (2003). Soil-to-plant transfer factors for natural radionuclides and stable elements in a Mediterranean area. J. Environ. Radioact. 65, 161-175. http://dx.doi.org/10.1016/S0265-931X(02)00094-2 
Table 1. Natural radionuclide contents in soil samples

\begin{tabular}{ccccccc}
\hline \multirow{2}{*}{$\begin{array}{c}\text { Sample } \\
\text { Code }\end{array}$} & \multicolumn{5}{c}{ Activity Concentration of Radionuclides in Soil Samples (in $\mathrm{Bq} \mathrm{kg}^{-1}$ ) } \\
\cline { 2 - 7 } & Range & Mean & Range & Mean & Range & Mean \\
\hline $\mathrm{D}_{1}$ & $47.8-76.4$ & 58.20 & $15.8-53.1$ & 39.1 & $128.4-433.6$ & 278.5 \\
$\mathrm{D}_{2}$ & $5-23$ & 11.60 & $9.5-34.2$ & 22.6 & $240.8-396.2$ & 308.3 \\
$\mathrm{D}_{3}$ & $13-29$ & 16.30 & $11-28.3$ & 20.7 & $53.5-166.2$ & 106.9 \\
$\mathrm{D}_{4}$ & $15-28.4$ & 23.70 & $12.7-16.5$ & 15.4 & $214-335$ & 285.3 \\
$\mathrm{D}_{5}$ & $1.8-4.6$ & 2.12 & $26.0-58.3$ & 37.7 & $231-360.7$ & 292.7 \\
$\mathrm{D}_{6}$ & $24.8-43.5$ & 37.9 & $16.1-47.5$ & 34.2 & $207.5-347.4$ & 304.6 \\
$\mathrm{D}_{7}$ & $9.16-14.3$ & 11.25 & $11.7-14.2$ & 13.8 & $154-233$ & 193.9 \\
$\mathrm{D}_{8}$ & $12.28-14.75$ & 13.04 & $30.5-85.5$ & 51.3 & $84-312$ & 256.2 \\
$\mathrm{D}_{9}$ & $11.16-13.82$ & 12.40 & $6.3-24.6$ & 15.7 & $468.9-516.7$ & 496.4 \\
$\mathrm{D}_{10}$ & $25.97-48.74$ & 33.80 & $25.4-33.2$ & 28.6 & $245.3-433.8$ & 327.4 \\
Average & & 22.03 & & 27.91 & & 285.02 \\
\hline
\end{tabular}

Table 2. Reported values of gamma activity in soil (activity $\mathrm{Bq} \mathrm{kg}-1$ ) samples, from the work conducted worldwide

\begin{tabular}{lcccc}
\hline \multicolumn{1}{c}{ Region (country) } & ${ }^{238} \mathrm{U}$ & ${ }^{232} \mathrm{Th}$ & ${ }^{40} \mathrm{~K}$ & Reference \\
\hline Tripoli, Libya & 10.5 & 9.5 & 270 & Shenber (1997) \\
Istanbul, Turkey & 21 & 37 & 342 & Karahan and Bayulken (2000) \\
Russiafa, Jordan & $48.3-523.2$ & $8.7-27.1$ & $44-344$ & Al-Jundi (2002) \\
Kalpakkam, India & $5-71$ & $15-776$ & $200-854$ & Kannan et al. (2002) \\
& $(16)$ & $(119)$ & $(406)$ & \\
Syria & 19 & 24 & 336 & Al- Masri et al. (2006) \\
World Average & 40 & 40 & 370 & UNSCEAR (2000) \\
\hline
\end{tabular}

Table 3. Dose rates in air from natural radionuclides in soil samples

\begin{tabular}{cccccc}
\hline Sample Code & \multicolumn{3}{c}{ Dose Rate in Air $\left(\mathrm{nGy} \mathrm{h}^{-1}\right)$} & & $\begin{array}{c}\text { Annual } \\
\text { Effective } \\
\text { Dose } \\
\end{array}$ \\
\cline { 2 - 4 } & \multicolumn{3}{c}{$\left.\mu \mathrm{Sv} \mathrm{y}^{-1}\right)$} \\
\hline $\mathrm{D}_{1}{ }^{238} \mathrm{U}$ & 24.85 & 25.88 & 11.98 & 62.71 & 76.96 \\
$\mathrm{D}_{2}$ & 4.95 & 14.96 & 13.26 & 33.17 & 40.71 \\
$\mathrm{D}_{3}$ & 6.96 & 13.70 & 4.59 & 25.25 & 30.99 \\
$\mathrm{D}_{4}$ & 10.12 & 10.19 & 12.27 & 32.58 & 39.98 \\
$\mathrm{D}_{5}$ & 0.91 & 24.96 & 12.59 & 38.46 & 47.20 \\
$\mathrm{D}_{6}$ & 16.18 & 22.64 & 13.10 & 51.92 & 63.72 \\
$\mathrm{D}_{7}$ & 4.80 & 9.14 & 8.34 & 22.28 & 27.34 \\
$\mathrm{D}_{8}$ & 5.57 & 33.96 & 11.02 & 50.55 & 62.04 \\
$\mathrm{D}_{9}$ & 5.29 & 10.39 & 21.35 & 37.03 & 45.44 \\
$\mathrm{D}_{10}$ & 14.43 & 18.93 & 14.08 & 47.44 & 58.22 \\
Average & 9.41 & 18.48 & 12.26 & 40.12 & 49.26 \\
\hline
\end{tabular}

